\title{
Evaluation of pre-germination treatments in Carapa guianensis AUBL.
}

\author{
Evaluación de tratamientos pre-germinativos en Carapa guianensis AUBL.
}

Pedro Pablo Baccaㅜ; Jhon Jairo Zuluaga²; Jose Ivez Perez ${ }^{3}$; Diana Lucía Burbano ${ }^{4}$; Manfred Ricardo Palacio5.

\begin{abstract}
ARTICLE DATA
Researcher, M.Sc., Corporación Colombiana de Investigación Agropecuaria - AGROSAVIA. Centro de Investigación el Mira, Tumaco, Colombia, pbacca@ agrosavia.co

2 Researcher, Ph.D., Corporación Colombiana de Investigación Agropecuaria - AGROSAVIA. Centro de Investigación Nataima, Espinal, Colombia, jzuluaga@ agrosavia.co

Researcher, M.Sc., Corporación Colombiana de Investigación Agropecuaria - AGROSAVIA. Centro de Investigación el Mira, Tumaco, Colombia, jiperez@ agrosavia.co

4 Researcher, Fundación Biofuturo. Bióloga. Profesional de investigación en Biología. Pasto, Colombia, dbiologia@ gmail.com

Researcher, Agricultural Engineer, Biologist, Corporación Colombiana de Investigación Agropecuaria - AGROSAVIA. Centro de Investigación el Mira, Tumaco, Colombia, mrpalacio@agrosavia.co
\end{abstract}

Citar: Bacca, P.; Zuluaga, J.; Perez, J.; Burbano, D.; Palacio, M. (2020). Evaluation of pre-germination treatments in Carapa guianensis AUBL. Revista de Ciencias Agrícolas. 37(2): 56-66.

doi: https://doi.org/10.22267/rcia.203702.138

Received: January 252019.

Accepted: December 102020.

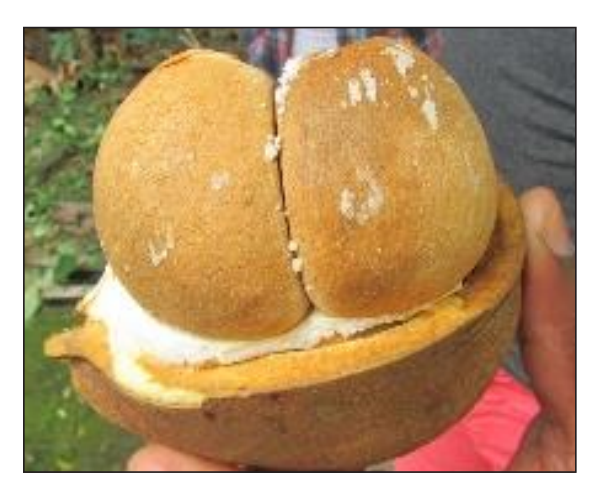

\section{ABSTRACT}

Understanding seed germination of native forest species of the Tropical wet forest is essential for ecosystem regeneration and conservation, which have been affected by the exploitation of wood and non-wood forest products. Carapa guianensis Aulb. (Meliaceae) has been exploited due to the high quality of its wood and seeds. Particularly, the latter is a source of a medicinal oil of high value to the pharmaceutical industry. The indiscriminate use of this species has reduced its population size; therefore, scientific knowledge of its sexual propagation in nurseries is vital. This research aimed to evaluate seed germination of $C$. guianensis under different pre-germination treatments and substrates at the Centro de Investigación El Mira of AGROSAVIA. Pregermination assays were conducted in a split-plot design with a random distribution of four repetitions. The cumulative germination percentage (CGP) and mean germination time $\left(t_{50}\right)$ were calculated and analyzed through an ANOVA, and Tukey's multiple comparison test using InfoStat V.2016. Significant differences for CGP among treatments $(p<0.0001)$ and interactions $(p<0.0096)$ were found. The highest germination percentage (61\%) was achieved in S1+T4; however, the $T_{50}$ did not show significant differences ( $p=0.24)$. This research demonstrates that the highest germination percentage is achieved through a scarification treatment with imbibition in sand substrate under the agroclimatic conditions of Tumaco.

Keywords: Andiroba; tropical wet forest; scarification; propagation; seeds.

\section{RESUMEN}

El estudio de la germinación de especies forestales nativas del bosque húmedo tropical es fundamental en la regeneración y conservación de este ecosistema, el cual se ha visto afectado por la explotación de los productos maderables y no maderables. En este sentido Carapa guianensis Aulb. (Meliaceae), ha sido aprovechada por su madera de alta calidad y semillas; de donde se obtiene aceite medicinal de alto valor para la industria farmacéutica. El uso indiscriminado ha disminuido su población, por cuanto generar conocimiento científico sobre 
su propagación sexual en vivero es de vital importancia. La presente investigación tuvo como objetivo evaluar la germinación de semillas de C. guianensis bajo diferentes tratamientos pre-germinativos y sustratos en el C.I El Mira de AGROSAVIA. Las pruebas pre-germinativas se realizaron mediante un diseño de parcelas divididas con cuatro repeticiones distribuidas al azar. Para el procesamiento de la información se calculó el porcentaje de germinación acumulada (PGA) y tiempo medio de germinación (t50). Los resultados se analizaron a través del ANOVA y de pruebas de comparación de Tukey mediante el programa estadístico InfoStat V.2016. Se obtuvieron diferencias significativas en PGA para los tratamientos ( $\mathrm{p}<0.0001)$ y las interacciones ( $\mathrm{p}<0.0096)$; en S1+T4, se alcanzó el mayor porcentaje de germinación (61\%). T50 no presentó diferencias significativas $(\mathrm{p}=0.24)$. La investigación demostró que, bajo las condiciones agroclimáticas del municipio de Tumaco, el tratamiento escarificación con imbibición en el sustrato arena proporcionó el mayor valor en la germinación.

Palabras clave: Andiroba; bosque húmedo tropical; escarificación; propagación; semillas.

\section{INTRODUCTION}

Tropical forests provide goods and ecosystem services that benefit the communities inhabiting these ecosystems; however, uncontrolled exploitation of wood and non-wood forest products drastically affects biodiversity and the abundance of certain native species (Palacios and Jaramillo, 2016). Indiscriminate deforestation reduces the number of seed trees; therefore, risking the future genetic base and seed propagation (Rojas, 2015). Furthermore, the scarcity of information about native forest species' propagation greatly adds to this problematic (Amaral et al., 2017).

Most tropical forest species propagate sexually; therefore, phytosanitary and genetic aspects are important to obtain quality seedlings that meet commercial expectations (Nascimento et al., 2019). However, many native species are not included in forest production plans and assessments of pregermination treatments, which is likely due to limited information in rural settings or restricted access to seeds. Furthermore, several industries, environmental authorities, and nursery growers require information about forest seeds' adequate management to achieve efficient and low-cost propagation (Nascimento et al., 2019).

Carapa guianensis Aubl. (Meliaceae), known as andiroba in Brazil (Gonçalves et al., 2018) and tangare in the Pacific coast of Nariño in
Colombia, is a promising native species of rapid growth, reaching a maximum height of $55 \mathrm{~m}$. It is distributed in South America and is native to the Amazon rainforest (Leite and Lima, 2018). This species displays important ecological characteristics, and high commercial value due to its wood and medicinal properties (Gonçalves et al., 2018; Reis et al., 2018) since the oil extracted from its seeds has pharmaceutical applications (Reis et al., 2018). Reproduction is mainly sexual (Lobo and Furtado, 2015); the fruit is a spherical capsule composed of eight seeds that animals disperse (May, 2016; Gonçalves et al., 2018; Leite and Lima, 2018). Seed harvesting is generally done by local communities who lack training regarding seed management, collection methods, or the plant population's analysis or successional structure (Guarino et al., 2014).

The exceptional characteristics of $C$. guianensis promote its high use; however, this exploitation considerably affects its population size and natural areas. Therefore, information about germination dynamics and seed morphology are important to establish seed collection and management guidelines to successfully propagate this species (Abbade and Takaki, 2014; Peixoto et al., 2019). For C. guianensis, germination behavior is variable; for instance, $24 \%$ to $90 \%$ germination can be reached in different periods ranging from days to months (Kossmann et al., 2002; Amaral et al., 2017; Hernández-Coronado et al., 2018). Therefore, 
nursery propagation alternatives for this species have led to the use of different pre-germination treatments such as mechanical scarification, sunlight exposure, and seed imbibition in sand and soil substrates (Torres et al., 2017). These methods provide adequate conditions to accelerate and increase germination of the embryo (Viveros et al., 2015).

In this context, and as part of the project entitled "Planification and management strategies for forest plantations in agroecosystems of Colombia", Corporación Colombiana de Investigación Agropecuaria (Colombian Corporation for Agricultural Research) - AGROSAVIA developed this study to evaluate to evaluate seed germination of $C$. guianensis under different pre-germination treatments and substrates in nursery conditions at the Centro de Investigación El Mira of AGROSAVIA.

\section{MATERIALS AND METHODS}

Location. This study was conducted at the Centro de Investigación el Mira of the Corporación Colombiana de Investigación Agropecuaria (AGROSAVIA), which is geographically located at $78^{\circ} 41^{\prime} 22^{\prime \prime} \mathrm{N}$ and $1^{\circ} 32^{\prime} 58^{\prime \prime} \mathrm{W}$, in Tumaco, Department of Nariño (Colombia). The study site is situated at an elevation of $16 \mathrm{~m}$ a.s.l., with a mean precipitation of $3067 \mathrm{~mm} /$ year, mean temperature of $25.5^{\circ} \mathrm{C}$, and relative humidity of $88 \%$ (Reyes et al., 2008).

Seed collection. This study used seeds from Salahonda in the municipality of Francisco Pizarro (Nariño) at $2^{\circ} 02^{\prime} 30^{\prime \prime} \mathrm{N}$ and $78^{\circ} 39^{\prime} 40^{\prime \prime} \mathrm{W}$. The seeds were collected from 10 trees according to the methodology described by Espitia-Camacho et al. (2018). The selected trees were visibly healthy and vigorous, with straight, long and accessible trunks, as Torres et al. (2017) recommended.

Physical description of the seed. A general description was made of the total seed lot based on eight samples composed of 100 units each, which were individually weighed on a Mettler Toledo tenth of a gram digital scale (Asociación Internacional de Pruebas de Semillas-ISTA, 2005; Espitia-Camacho et al. 2018). Next, the biometric properties of the seeds from each repetition were determined based on the following variables: width ( $\mathrm{mm})$, length $(\mathrm{mm})$, and thickness $(\mathrm{mm})$, measured using a Mitutoyo digital caliper. Diseased and infected seeds were discarded (HernándezCoronado et al., 2018) (Figure 1).
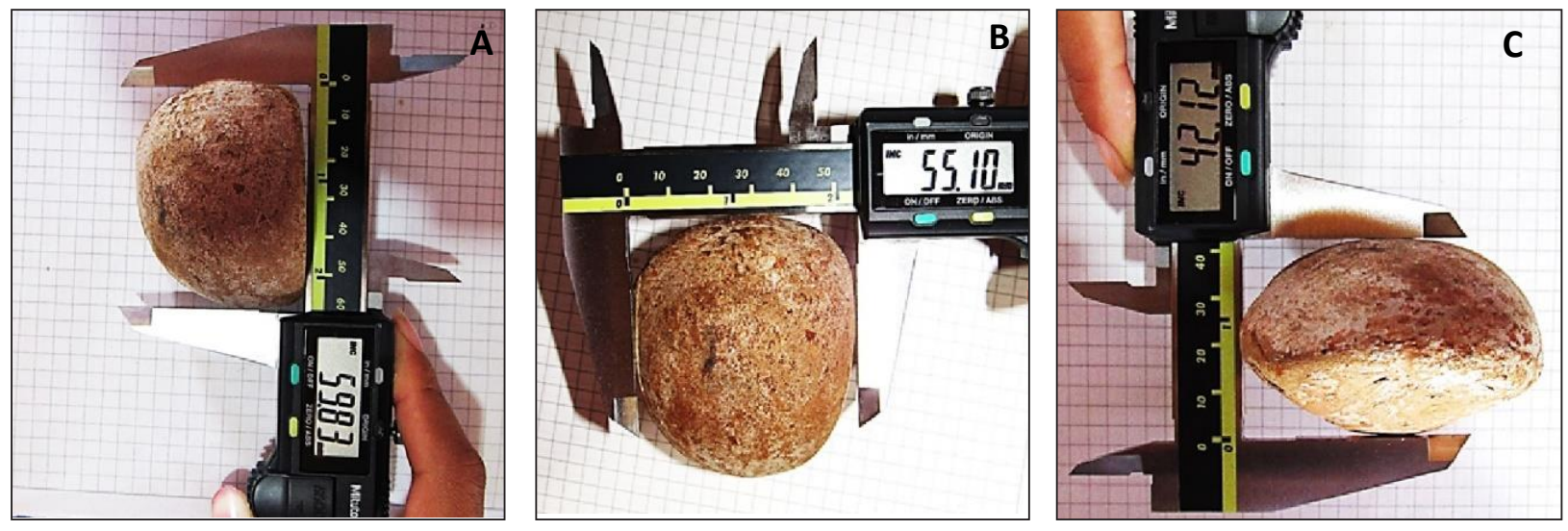

Figure 1. Seeds of $C$. guianensis. A: length (mm), B: width (mm), C: thickness (mm). 
Pre-germination treatments and substrates. Three pre-germination treatments and a control were performed (Table 1). According to the study by García et al. (2019), the pre-germination treatments were selected for tropical forest species. The substrates were selected based on Lobo and Furtado (2015), with modified proportions.

Table 1. Pre-germination treatments and substrates used for propagating C. guianensis.

\begin{tabular}{ll}
\hline Pre-germination treatments & \multicolumn{1}{c}{ Substrate } \\
\hline T1: control without treatment & S1: sand (100\%) \\
T2: sunlight exposure for 24h + imbibition for 24h & S2: sand and soil (50\%-50\%) \\
T3: mechanical scarification & S3: soil (100\%) \\
T4: mechanical scarification + imbibition for 24h & \\
\hline
\end{tabular}

The substrates were disinfected with dazomet (Theaux, 2015) at a dose of $40 \mathrm{~g} \mathrm{per}^{2}$; then, the substrate was covered with plastic for five days and left to settle for 12 more days.

Experimental design. A randomized blocks design with split-plots and four repetitions was implemented. The large plots corresponded to the substrates, namely sand (S1), sand and soil (S2), and soil (S3) (Santiago et al., 2015). Furthermore, the subplots corresponded to the seed treatments: control without treatment (T1), T2: sunlight exposure for $24 \mathrm{~h}+$ imbibition for $24 \mathrm{~h}$ (T2), mechanical scarification (T3), and T4: mechanical scarification + imbibition for 24h (T4). In total, 12 combinations were obtained, and the experimental unit was 20 seeds/pre-germination treatment for a total of 960 seeds (ISTA, 2005) (Figure 2).
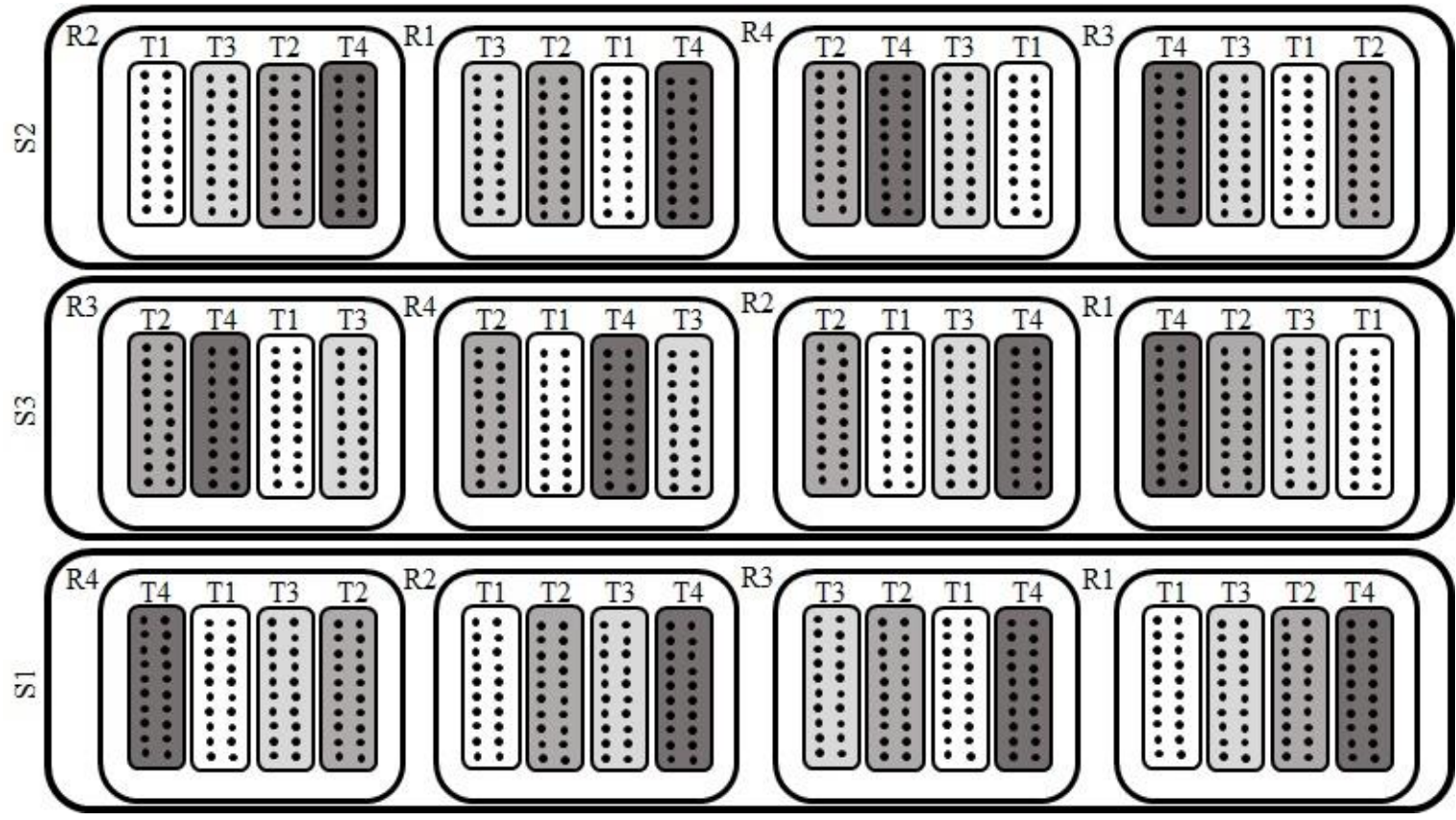

Figure 2. Split-plots design: the main plot = substrates $(\mathrm{S} 1, \mathrm{~S} 2, \mathrm{~S} 3)$, the subplots = treatments (T1, T2, T3, T4) and four repetitions (R1, R2, R3, R4). 
The effects of the pre-germination treatments and substrates were measured as the cumulative germination percentage (CGP) and mean germination time $\left(t_{50}\right)$ (Lobo and Furtado, 2015). Furthermore, the initial and final germination percentages were determined (Torres et al., 2017). After planting, the number of germinated seeds was recorded daily until day 42 (i.e., when germination remained constant). A seed was considered to have germinated when the epicotyl grew to at least $1 \mathrm{~cm}$ (Céspedes, 2018).

The CGP was calculated per experimental unit for each substrate, according to equation 1 :

$$
\mathrm{CGP}=(\mathrm{Sg} / \mathrm{Ss}) * 100 \%
$$

Where:

$\mathrm{Sg}=$ Number of germinated seeds and

Ss $=$ Number of planted seeds.

The $t_{50}$ was calculated according to equation 2 proposed by Ellis and Roberts (1978). This equation establishes the time needed to reach 50\% seed germination (Sánchez-Soto et al., 2017).

$$
\mathrm{t}_{50}=\frac{[(N / 2)-N 1) *(T 2-T 1)]}{N 2-N 1}+T 1
$$

Where:

$\mathrm{N}=$ Final $\%$ of germinated seeds.

$\mathrm{N}_{1}=\%$ of germinated seeds prior to $\mathrm{N} / 2$.

$\mathrm{N}_{2}=\%$ of germinated seeds after to $\mathrm{N} / 2$.

$\mathrm{T}_{1}=$ Number of days for $\mathrm{N} 1$.

$\mathrm{T}_{2}=$ Number of days for $\mathrm{N} 2$.

$t_{50}=$ Number of days for $\mathrm{N} / 2$.

Statistical analysis. The statistical tests were performed using InfoStat version V. 2016. The variables were tested for normality, using the Shapiro-Wilk test and Q-Q plots, as well as homoscedasticity. The treatments, substrates, and their interaction (treatments with substrates) were analyzed by a variance analysis (ANOVA), followed by Tukey's multiple comparison test. This same analysis was performed for the time of onset of germination and meantime of germination. $P$-values less than 0.05 were considered significant $(P<0.05)$ (Zar, 2010).

\section{RESULTS AND DISCUSSION}

Physical description of the seed. The seed weight of $C$. guianensis varied within a broad range (i.e., from $23.36 \mathrm{~g}$ to $49.60 \mathrm{~g}$ ), with an average of $35.7 \mathrm{~g}$. This value is higher than reported by Hernández-Coronado et al. (2018), who found an average weight of $22.1 \mathrm{~g}$ based on 100 seeds. Similarly, Kossmann et al. (2002) reported weights between 25 and $32 \mathrm{~g}$ and established that 30-50 seeds are required to obtain $1 \mathrm{~kg}$. In this study, the data indicates that approximately 28 seeds are required per kg. Peixoto et al. (2019) found different weights for $C$. guianensis, even seeds from the same fruit, and determined that this variability could be associated with the nondomestication of this species.

The other biometric parameters, such as length, width, and thickness of C. guianensis seeds, (Table 2) also showed higher variation than in Teixeira et al. (2019), who reported mean values $38.21,33.56$, and $32.95 \mathrm{~mm}$, respectively. Several researchers indicate that the agroclimatic conditions of the site can affect seed development, leading to variations in seed size, weight, and morphology (Peixoto et al., 2019). Based on the results shown in Table 2, this seed can be considered extremely large compared to other forest seeds, according to the manual of tropical and subtropical seeds of ISTA (2005). 
Table 2. Biometric data of the seed of $C$. guianensis.

\begin{tabular}{lc}
\hline \multicolumn{1}{c}{ Variable } & Mean value \pm SD \\
\hline Weight $(\mathrm{g})$ & $35.7 \pm 6.07$ \\
Length $(\mathrm{mm})$ & $59.1 \pm 3.59$ \\
Width $(\mathrm{mm})$ & $54.8 \pm 3.28$ \\
Thickness $(\mathrm{mm})$ & $43.2 \pm 4.16$ \\
\hline
\end{tabular}

SD: Standard deviation.

Evaluation of germination. The CGP did not show significant differences in response to the substrate $(P=0.9453)$; therefore, this variable did not affect germination. These results differ from reports by Severino et al. (2005) indicated that forest seeds' germination depends on the substrate since it provides different physical factors such as aeration and humidity. The pregermination treatments showed significant differences in CGP $(P<0.0001)$, as well as the interaction between substrates and pregermination treatments $(P<0.0096)$ (Table 3$)$.
Table 3. Results of the analysis of variance (ANOVA) for the split-plots.

\begin{tabular}{lcc}
\hline \multicolumn{1}{c}{ F of V } & DF & \multicolumn{1}{c}{$\boldsymbol{P}$-value } \\
\hline Model & 20 & $<0.0001^{* * *}$ \\
Substrates & 2 & $0.9453 \mathrm{~ns}$ \\
Error Factor A & 9 & 0.0018 \\
Treatments & 3 & $<0.0001^{* * *}$ \\
Interaction & 6 & $0.0096^{* *}$ \\
Error Factor B & 27 & - \\
Total & 47 & - \\
\hline
\end{tabular}

F of V; factor of the variable. DF; degrees of freedom. p: probability limits of the ANOVA. **: $P<0.01$; ${ }^{* *}: P<0.001$; ns: $P>0.05$. R squared $=0.93 . \mathrm{CV}=24.25$ Factors: factor $\mathrm{A}$ : substrates on germination $\%$ and factor B: treatments on germination $\%$.

For pre-germination treatments, Tukey's multiple comparison test indicated that treatments $\mathrm{T} 3$, and $\mathrm{T} 4$ had the highest values with similar means; therefore, these treatments do not differ and either pre-germination method is suitable (Figure 3).

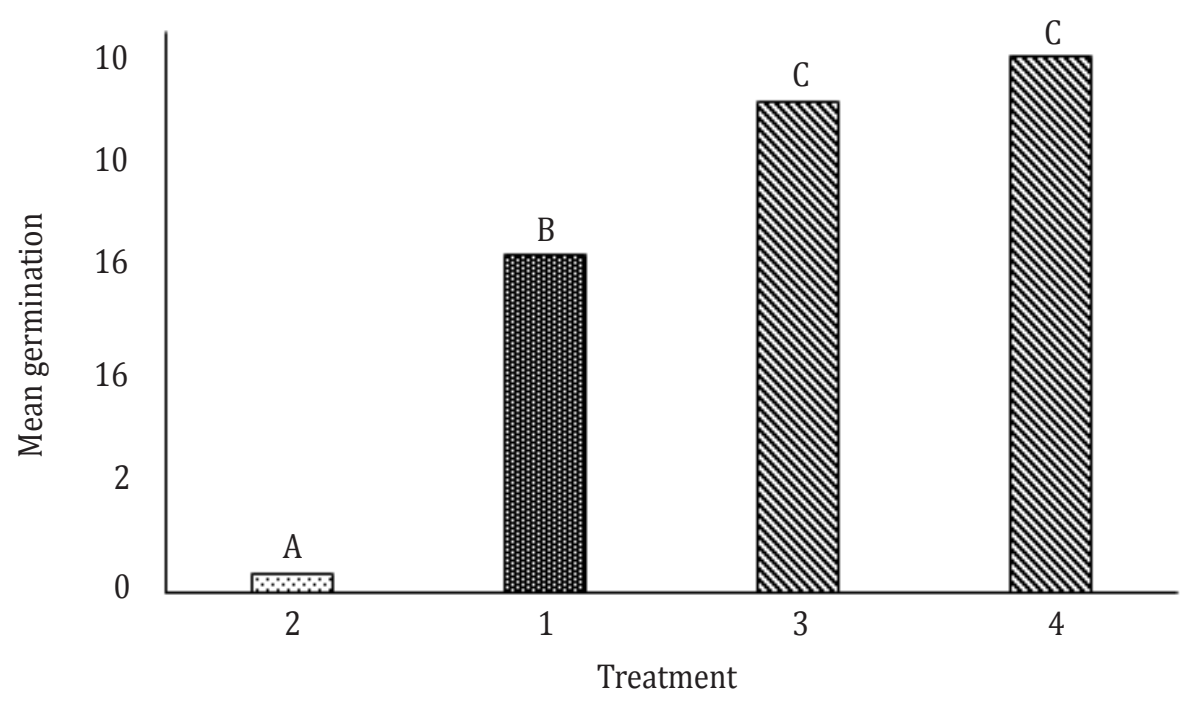

Figure 3. Cumulative germination per pre-germination treatment. Tukey's multiple comparison test. Different letters above the columns indicate a significant difference (Tukey. $P<0.05$ ). 
According to Figure 3, T2 does not promote germination; this finding differs from Lobo and Furtado (2015) reports. These authors assessed the effect of different levels of sunlight on $C$. guianensis and established that germination is significantly promoted under all light intensity levels. Bewley et al. (2013) mention that sunlight exposure can cause water deficits in seeds, affecting the velocity and final germination percentage andgermination variability. The results found here suggest that sunlight exposure likely induces photoinhibition of germination; thus, negatively affecting propagation. Several authors suggest that this type of seeds should be planted immediately after collection (Sánchez et al., 2015).

Tukey's multiple comparison test for the interaction between treatments and substrates (Figure 4) indicated five groups (A, B, BC, CD, D). Furthermore, T4 in S1 shows the highest mean germination $(\bar{x}=12.25)$, equal to $61 \%$ germination. The cumulative germination percentage (Figure 5) was congruent with this result; accordingly, T4 in S1 showed the highest germination percentage than other substrates and treatments. Overall,
C. guianensis was found to germinate gradually, which agrees with reports by Villota (2016) and Hernández-Coronado et al. (2018).

No significant differences $(P=0.32)$ were found for the initial germination percentage, as shown in Figure 5. However, the highest value was found for T4 in S2, it reached 8\% germination on day 18 of the experiment (Figure 5B). Villacorta (2010) reported the same results and determined that this species' onset of germination occurred on day 18 after planting, based on a previous imbibition treatment for 48 hours at room temperature. However, these results differ from those found by Vianna (1982), who assessed the behavior of Andiroba seeds in Tapajos National Forest (Santarém. PA). The author reported that onset of germination occurred at day 1 , without applying pre-germination treatments. Conversely, Villota (2016) reported that the onset of Carapa amorphocarpa $\mathrm{W}_{\text {., a species of the same }}$ family, occurred on day 43 in sand + soil substrate. Sanchez et al. (2019) indicated that C. guianensis develops better in very humid substrates, such as soil, storing and retaining moisture.

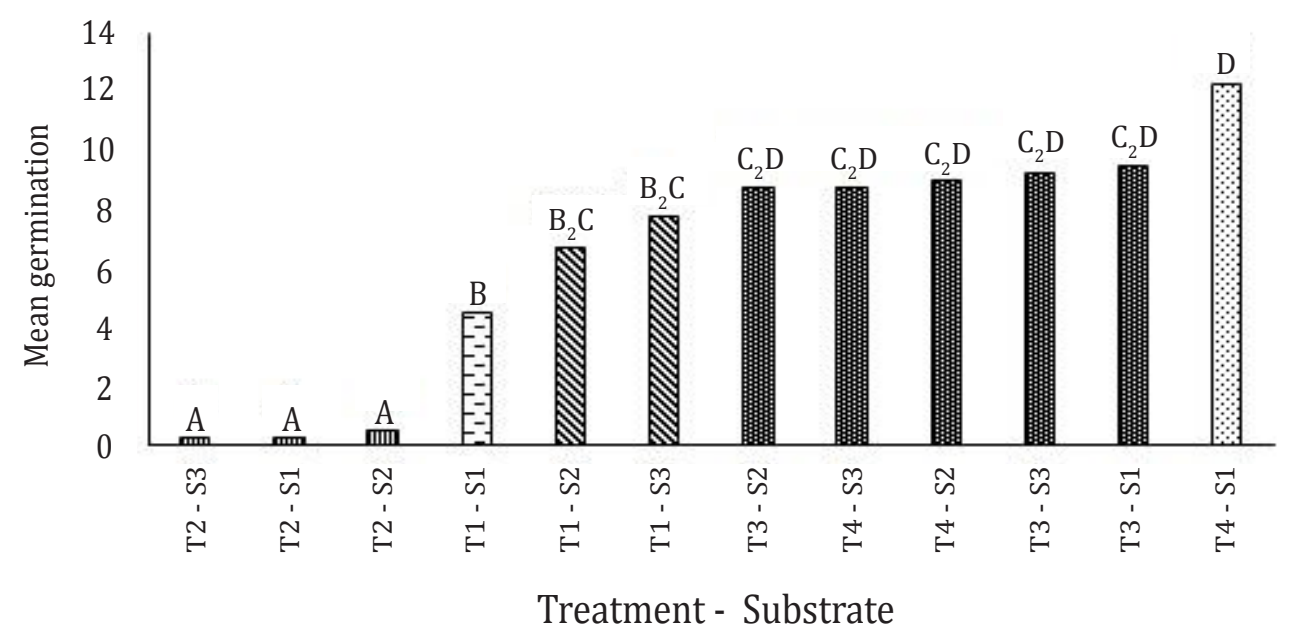

Figure 4. Cumulative germination for pre-germination treatments and substrates interaction. Tukey's multiple comparison test. Different letters above the columns indicate significant differences (Tukey. $P<0.05$ ). 

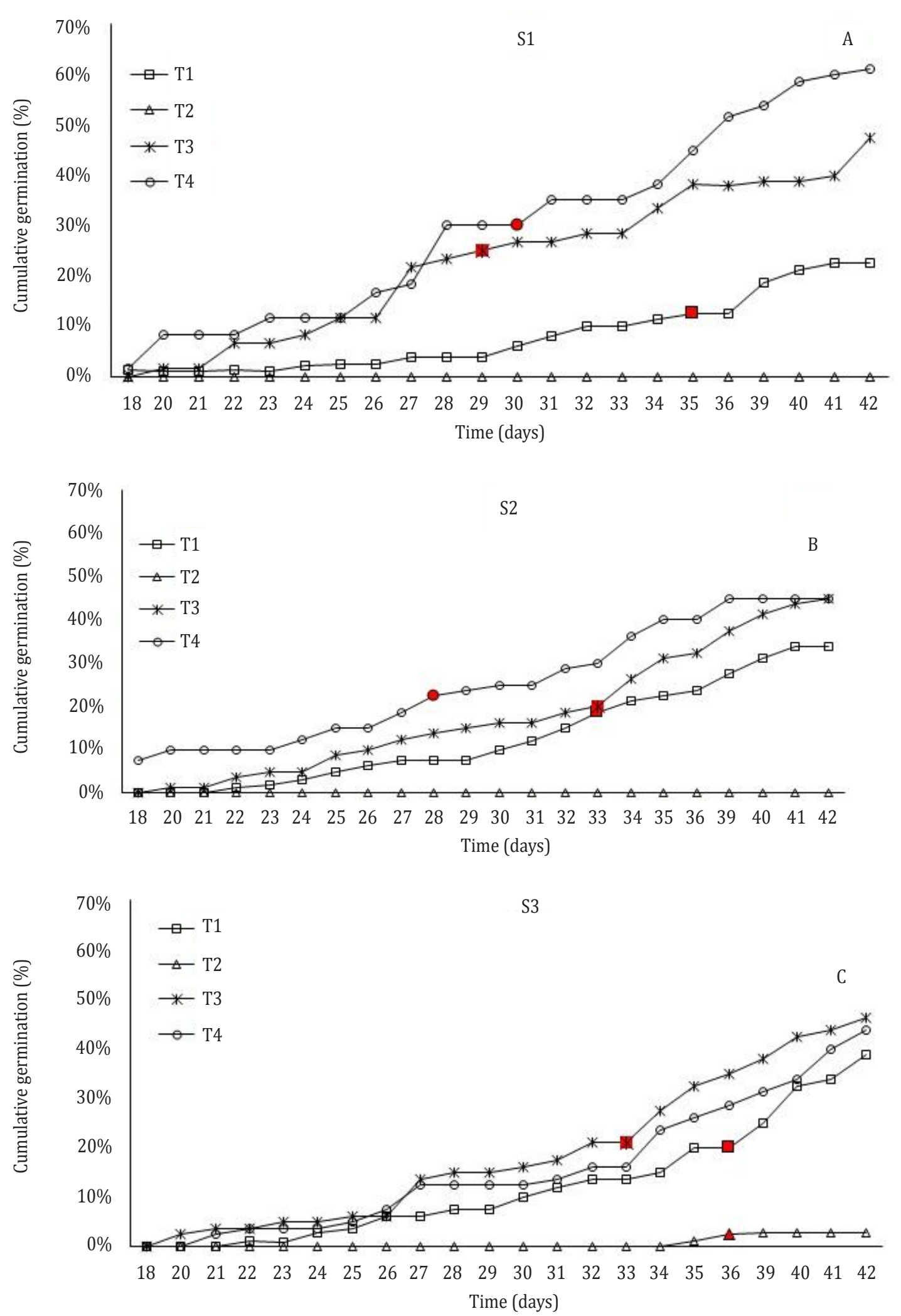

Figure 5. The Behavior of the cumulative germination percentage of $C$. guianensis. A: S1; B: S2; C: S3 under pre-germination treatments: T1; T2; T3; T4. Shapes in red: mean germination time $\left(t_{50}\right)$. 
Regarding the final germination percentage (Figure 5), T4 in S1 reached 61\% after 42 days (Figure $5 \mathrm{~A}$ ), while $\mathrm{T} 2$ showed $0 \%$ to $3 \%$ germination in the same period. These results exceed those reported by Kossmann et al. (2002). He determined that C. guianensis only reached 30\% germination in 40 dayswithout any treatment. Scarano et al. (2003) a hard wood tree from the Brazilian Amazon, has large recalcitrant seeds that can germinate and establish in both flood-free (terra-firme mention that $88 \%$ of seeds germinated after 30 days, $82 \%$ after 2 months, and $70 \%$ after 90 days after a flotation technique applied to different seed lots of $C$. guianensis.

There were no significant differences $(P=0.24)$ in $t_{50}$ for the total number of germinated seeds. The mean germination time ranged from 28 to 36 days. The lowest value was obtained for T4 in S2 $\left(t_{50}=28\right.$ days with $23 \%$ germination), indicating that less time was required to reach $50 \%$ germination than in other treatments and substrates. Meanwhile, T2 in S3 $\left(t_{50}=36\right.$ days with $\left.3 \%\right)$ showed the highest mean germination time. Nevertheless, this result is lower than Myers (2013) reported because he found a mean germination time of 65 days of $C$. guianensis. The results differ from those reported for Swietenia macrophylla King., a species of the same family (Meliaceae) since it displays a germination time ranging from 8 to 14 days (Céspedes, 2018). Therefore, seed germination and establishment requirements are species-specific and are influenced by the characteristics of the region that the species has adapted to (Sánchez et al., 2019).

\section{CONCLUSIONS}

The C. guianensis seeds' biometric characteristics from Tumaco-Nariño allow classifying the seeds as relatively large (weight: $35.7 \mathrm{~g}$, length: $59.1 \mathrm{~mm}$, width: $54.8 \mathrm{~mm}$, and thickness: $43.2 \mathrm{~mm}$ ).

A comparison of the CGP of $C$. guianensis reported in different studies, including this study, shows that germination is highly variable and likely depends on agroecological conditions.

By comparing the CGP with other studies, we determined that germination of $C$. guianensis is highly variable and it likely depends on the agroecological conditions of the site. Therefore, in ecosystems similar to the one found in TumacoNariño, the interaction of mechanical scarification + imbibition for $24 \mathrm{~h}$ in sand substrate allows cumulative germination of $61 \%$.

The mean germination time ranged from 28 to 36 days; however, it was not affected by the pregermination treatments and substrates used, indicated by non-significant differences.

\section{ACKNOWLEDGMENTS}

The authors thank the Corporación Colombiana de Investigación Agropecuaria (Colombian Corporation for Agricultural Research) (AGROSAVIA) for funding this study and the professional support team at C.I El Mira for their support in collecting the information.

Conflict of interest: The authors declare that there is no conflict of interest.

\section{BIBLIOGRAPHICAL REFERENCES}

Abbade, L.; Takaki, M. (2014). Teste de tetrazólio para avaliação da qualidade de sementes de tabebuia roseoalba (ridl.) Sandwith - Bignoniaceae, submetidas ao armazenamiento. Revista Árvore, Viçosa-MG. 38(2): 233-240.

Amaral, T.; Furtado, H.; Sousa, L.; Vilas, R.; Rodrigues, W.; Costa, M. da. (2017). Germinação de sementes e crescimento de mudas de andiroba (Carapa guianenses Aubl.) em diferentes substratos orgânicos. Brasil: XXX CBA Congreso Brasilero de Agronomia.. 
Bewley J.D.; Bradford K.J.; Hilhorst H.W.M.; Nonogaki H. (2013). Seeds: Physiology of development, germination and dormancy (3rd edition). New York: Springer.

Céspedes, K. (2018). Determinación de los patrones de tinción y efecto de la giberelina sobre la germinación de las semillas de caoba (Swietenia macrophylla) y guayacán amarillo (Handroanthus chrysanthus). Colombia: Universidad distrital Francisco José de Caldas.

Ellis, R.H.; Roberts, E. H. (1978). Towards a rational basis for testing seed quality.. In: Hebblethwaite, P.D. pp: 605-636. (ed.). Seed Production. London: Butterworth.

Espitia-Camacho, M.; Araméndiz-Tatis, H.; CardonaAyala, C. (2018). Biométricas del fruto y semillas en genetic parameters of fruit and seed biometric characteristics in Pachira aquatica Aubl. Rev. U.D.C.A. Act \& Div. Cient. 21(1): 33-42. doi: https:// doi.org/10.31910/rudca.v21.n1.2018.660

García, G.; Camilo, B.; Quintero, L.; Guzmán, D. P.; Álvarez, J. (2019). Evaluación de la germinación de Aniba perutilis Hemsl. (Comino crespo), procedente del municipio de San Carlos (Antioquia), para el establecimiento de fuentes semilleras. Encuentro Sennova Del Oriente Antioqueño. 8-16.

Gonçalves, H.; Alves, K.; Ferreira, M.; Carvalho, A.; Lameira, 0. (2018). Fenologia reprodutiva de Carapa guianensis Aubl. no horto de plantas medicinais da embrapa amazônia oriental. Recovered from https://ainfo.cnptia.embrapa.br/ digital/bitstream/item/192728/1/FENOLOGIAREPRODUTIVA.pdf

Guarino, E. D. S.; Gessner, C.; Oliveira, L. de; Lopes, F.; Raposo, A. (2014). Estrutura etária e espacial de uma população natural de Carapa guianensis Aubl. (Meliaceae) na Amazônia Sul Ocidental Age and spatial structure of Carapa guianensis Aubl. (Meliaceae) in southwestern Amazon. Scientia Forestal. 42(101): 91-99.

Hernández-Coronado, A.; Rodríguez, A.; Candre, A.; Pinto, I.; Bernilla, A. (2018). Estudio de viabilidad y conservación de semillas de cinco especies vegetales amazónicas como base para la creación de un banco de germoplasma en el municipio de Leticia, Amazonas, Colombia. Revista del Instituto de Investigaciones de la Amazonía Peruana, 27(1): 9-23. doi: https://doi.org/10.24841/fa.v27i7.435.
ISTA - International Seed Testing Association. (2005). ISTA handbook on seed sampling (2nd ed.). Bassersdorf, Switzerland: ISTA.

Kossmann, I.; Campana, J.; Barbosa, P. (2002). Sementes e plântulas de andiroba (Carapa guianensis AUBL. e Carapa procera D. C.): aspectos botânicos, ecológicos e tecnológicos. Acta. 32(4): 647-661.

Leite, A.; Lima, K. (2018). Uso de óleo de andiroba (Carapa guianensis) na produção de velas artesanais como instrumento para o ensino de Química.Ex@ tas Online. 9(2): 39-52.

Lobo, L.; Furtado, A. (2015). The effect of light quality, temperature and substrate on seed germination and epicotyl development of Carapa guianensis, a multi-use neotropical tree. Journal of Medicinal Plants Research. 9(18): 582-593. doi: https://doi. org/10.5897/jmpr2014.5736

May, T. (2016). Aspectos de sostenibilidad de productos no maderables forestales con uso curativo en el oeste de Pará, Brasil * Aspects of Sustainability of Non-timber Forest Products Used for Health in Western Pará, Brazil Aspects de la durabilité de produits forestie. Ambiente y Desarrollo. 20(38): 69-84. doi: https://doi.org/10.11144/Javeriana. ayd20-38.aspm

Myers, R. L. (2013). Germinación de semillas y supervivencia de plántulas en pantanos dominados per yolillo Raphia taedigera (Arecaceae) en las Llanuras de Tortuguero, Costa Rica. Revista de Biología Tropical. 61(1): 47-66.

Nascimento, G. O.; Souza, D. P.; Santos, A. S.; Batista, J. F.; Rathinasabapathi, B.; Gagliardi, P. R.; Gonçalves, J. F. C. (2019). Lipidomic profiles from seed oil of Carapa guianensis Aubl. and Carapa vasquezii Kenfack and implications for the control of phytopathogenic fungi. Industrial Crops and Products. 129: 67-73. doi: https://doi.org/10.1016/j.indcrop.2018.11.069

Palacios, W. A.; Jaramillo, N. (2016). Árboles amenazados del Chocó ecuatoriano. Avances en Ciencias e Ingeniería. 8(14): 51-60. doi: https://doi. org/10.18272/aci.v8i1.508

Peixoto, A.; Braga, A.; Lima, R.; Sousa, N.; Fragoso, L.; Reis, M.; Cunha, W.; Pinheiro, A.; Resende, V.; Ferreira, C. (2019). Emergency and Growth of Andiroba Seedlings (Carapa guianensis Aubl.) in Function of the Seeds. Journal of Agricultural 
Science. 11(9): 293. doi: https://doi.org/10.5539/ jas.v11n9p293

Reis, J.; Lourenço, L.; Madeira, C.; Santos, J. Dos; Nascimiento, M. Do. (2018). Caracterização histoquímica de andiroba (Carapa guianensis aubl.), para fins fitoterápicos. Recovered from https:// www.researchgate.net/publication/330907685_ CARACTERIZACAO_HISTOQUIMICA_DE_ ANDIROBA_CARAPA_GUIANENSIS_AUBL_PARA_ FINS_FITOTERAPICOS

Reyes, R.; Rodríguez, N.; Peña, E.; Bastidas, S. (2008). Crecimiento en vivero de materiales comerciales de palma aceitera (Elaeis guineensis Jacq.) en Tumaco, Colombia. Corpoica Cienc Tecnol Agropecu. 9(2):12-18.

Rojas, D. (2015). Árbol de comino (Aniba perutilis Hemsley) una planta maderable en peligro de extinción en el sur del departamento del Huila [Universidad Nacional Abierta y a Distancia UNAD]. Recovered from http://repositorio.unan.edu. ni/2986/1/5624.pdf

Sánchez-Soto, B.; Pacheco-Aispuro, E.; Lugo-García, G.; Reyes-Olivas, Á.; García-Montoya, E. (2017). Scarification methods in seeds of Guaiacum coulteri, an endangered species that inhabits the tropical deciduous forest of northern Sinaloa, Mexico. Gayana Bot. 74(2): 262-268. doi: https:/doi. org/10.4067/S0717-66432017000200262

Sánchez, A.; Montejo, L.; Gamboa, A.; Albert-Puentes, D.; Hernández, F. (2015). Germinación y dormancia de arbustos y trepadoras del bosque siempreverde de la Sierra del Rosario, Cuba. Pastos y Forraje. 38(1): 11-28.

Sanchez, J.; Pernus, M.; Torres-Arias, Y.; Barrios, D.; Dupuig, Y. (2019). Germination ecology of seeds the tropical and subtropical zones, Cuba View project Current and future potential distribution of the flora and fauna of Cuba: exploring the effects of climate change on terrestrial biota View project. Acta Botánica Cubana. 218(2): 77-108. doi: http:// orcid.org/0000-0002-7118-8608

Santiago, 0.; Vargas, J.; Aldrete, A.; López, J.; Fierros, A. (2015). Sustratos y tamaños de contenedor en el desarrollo de Hevea brasiliensis Müll. Arg. en vivero. Revista Mexicana de Ciencias Forestales. 6(31): 94-113.

Scarano, F. R.; Pereira, T. S.; Rôças, G. (2003). Seed germination during floatation and seedling growth of Carapa guianensis, a tree from flood-prone forests of the Amazon. Plant Ecology. 168(2): 291-296. doi: https://doi.org/10.1023/A:1024486715690

Severino, L. S.; Dionízio, C. G.; Lucena, A. M. A. (2005). Seedling emergence and germination of castor seed planted in different positions. Revista de Biologia e Ciências da Terra. 5(1).

Teixeira, M.; Cardoso, M.; Silva, J.; Araújo, B. De.; Sousa, T.; Piloni, M. (2019). Biometria de sementes de andiroba (Carapa guianensis e Carapa procera) de duas diferentes áreas. In: Carvalho, A. (Ed.), Ciências Agrárias: Campo Promissor em Pesquisa 2 pp. 56-61. Jardim Carvalho: Atena Editora. doi: https://doi. org/10.22533/at.ed.1601920068

Theaux, P.; Lucalioli, V.; Kiehr, M.; Marinangeli, P. (2015). Influencia de la desinfección química de un sustrato con dicloropropneo + cloropicrina o con dazomet, sobre parametro de calidad de plantines de Primula acaulis. Bahía Blanca: Congreso Argentino de Horticultura.

Torres, J.; Medina, H.; Pinilla, H.; Córdoba, E.; Martínez, M. (2017). Propagación en vivero de la especie forestal Dipteryx oleifera Benth. mediante semillas. Revista Politecnica. 13(24): 19-26.

Vianna, N. (1982). Conservação de Sementes de Andiroba (Carapa guianensis AUBL.), Brasil: EMBRAPA-CPATU-Circular técnica.

Villacorta, M. (2010). Ensayo de propagación y crecimiento inicial de Carapa guianensis en vivero, CIEFOR. Perú: Universidad nacional de la amazonia peruana.

Villota, F. (2016). Propagación de Carapa amorphocarpa $W$. empleando diferentes tratamientos, en el noroccidente del Ecuador. Ecuador: Universidad Técnica del Norte.

Viveros, H.; Hernández, J. D.; Velasco M. V.; Robles, R.; Ruiz, C.; Rentería, A. A.; Martínez M. de J.; Hernández, J.; Hernández, M. L.; (2015). Analisis de semilla, tratamientos pregerminativos de Enterolobium cyclocarpum (Jacq.) Griseb. y su crecimiento inicial. Revista Mexicana de Ciencias Forestales. 6(30): 52-65. 